\title{
TRADE ON NON-TIMBER FOREST PRODUCTS (NTFPS) BETWEEN SOUTH WEST CAMEROON AND NIGERIA
}

\author{
A. F. NKWATOH, L. POPOOLA, S. M. IYASA, F. W. NKWATOH
}

(Received 14 April 2009; Revision Accepted 15, January 2010)

ABSTRACT

The study assessed the Non-Timber Forest Products (NTFPs) of the Ejagham Forest Reserve and its Adjoining Forest in general and those traded between Cameroon and Nigeria in particular. This was carried out within a period of ten months, December - April 2006 (for the dry season) and June - October 2007 (for the wet season). The line transects questionnaires, and a selection of some Participatory Rural Appraisal (PRA) tools were used for the collection of data while the Statistical Package for the Social Sciences (SPSS) was used for data analysis. The study identified about 36 NTFPs species in the area that are sourced by local people for local and external trade and household consumption. From the list of 36, Irvingia, Gnetum, Carpolobia, Masularia, and Ricinodendron species were identified as the five tradable NTFPs of the study area involved in Trans-boundary trade between Cameroon and Nigeria. These NTFPs were observed to be sourced from the primary and secondary forests, fallow and farm lands. The collection, harvesting and gathering methods for these NTFPs were observed to be traditional and associated with resource degradation.

KEY WORDS: NTFPs, Trade, Trans-boundary, Ejagham, Forest Reserve.

\section{INTRODUCTION}

Forest, apart from timber, forest contains many useful goods and services of subsistence and commercial value called Non-Timber Forest Products (NTFPs), which sustain the rural people and rural economies. According to Adeyoju (1975) and Ndouye et al (1998), the consumption, trade and identity of these goods and services, are not properly documented. This has led to gross under-valuation of the enormous socioeconomic and cultural significance of these resources. Falconer $(1990,1992)$ defines NTFPs as all forest goods and services, excluding commercial timber. In this context, NTFPs include such diverse products as animal products, leaves, local building materials, edible fungi, medicinal plants, forest foods, sponges, chewing sticks, fibres, gums and rattan canes, among others. These products constitute rural industrial raw materials for cottage industries, cultural symbols, ritual artefacts and traditional medicine (Docan and Mbenkum, 1989, FAO, 1988). Despite their huge contribution, the sector has been subjected to misuse. Padoch and de Jong, 1995; and Ndouye et al 1997 agreed that, this has been due to lack of appropriate information on their occurrences and prevalence, the growing socio-economic and cultural potentials of these products in the developing and the developed economies of the world.

In the Humid Lowlands of Central and West Africa
(HULCWA), there are many of these products in used and their occurrence and prevalence varies among component ecological sub-zones and habitat types. In the past three decades, these NTFPs have attracted greater attention of scientist in the sub-region.

Prominent scientists have carried out research on the prevalence, phenology, socio-economics, genetics and domestication of many of this specie. Among these are studies by Okafor $(1981,1986)$ who focused mainly on edible indigenous fruit plants and their importance in rural economy of Nigeria. Egunjobi and Lawal (1973) studied the un-exploited plant resources of Nigeria. Ladipo (1995) worked on collection and conservation of the genetic resources of Irvingia gabonensis in West and Central Africa. Doncan and Mbenkum (1987) looked at the ethnobotany of Korup National Park, while Popoola and Oluwalana (1998), Ndonye et al (1998), Omoluabi (1994), and Nkwatoh (2000) studied the marketing of NTFPs in Cameroon and Nigeria.

Despite all these research efforts, NTFPs are still not receiving the adequate attention they deserve from policy makers, stakeholders in Cameroon in particular and the Central and West African Sub-regions in general. Hence, many of these forest resources are becoming scarce, threatened, endangered and extinct in extreme cases.

A. F. Nkwatoh, Department of Geology and Environmental Science, University of Buea, P.O. Box 63 Buea, South West Region, Cameroon.

L. Popoola, Department of Geology and Environmental Science, University of Buea, P.O. Box 63 Buea, South West Region, Cameroon.

S. M. Iyasa, Department of Geology and Environmental Science, University of Buea, P.O. Box 63 Buea, South West Region, Cameroon.

F. W. Nkwatoh Department of Geology and Environmental Science, University of Buea, P.O. Box 63 Buea, South West Region, Cameroon. 
One of the major problems facing the NTFPs sector today in Cameroon is the lack of any correlated research that matches biological data with socio-economic activities. As part of the national drive to source adequate information, on what constitutes the National Stock of NTFPs in the Country, this study assessed what constitutes the NTFPs list of the Ejagham Forest Reserve area and the species that are tradable between Nigeria and Cameroon, as a contribution to this national drive. To achieve this, the study examined the following general and specific objectives:

\section{OBJECTIVES OF THE STUDY}

The general objective of the study was to produce a comprehensive list of NTFPs in the Ejagham Forest Reserve and its adjoining villages that sustains rural livelihoods as well as national and international economies.

\section{SPECIFIC OBJECTIVE}

The specific objectives of the study were as follows: i) Identify the existing NTFPs in the study area; ii) With the active participation of all the forest stakeholders, find out the existing NTFPs in the study area that are traded between Cameroon and Nigeria; iii) Examine the harvesting, collection and gathering methods for the trans-boundary traded NTFPs; iv)Trace channels of trade on these NTFPs in the study area.

\section{Study Area}

The study area (Ejagham Forest Reserve and its adjoining Villages) is located in the South West Region of Cameroon. It extends from latitude $50^{\circ} 10^{\circ}$ to $50^{\circ} 70^{\prime} \mathrm{W}$ and from longitude $80^{\circ} 47^{\prime}$ to $90^{\circ} 11^{\prime} \mathrm{S}$, and shares part of its western border with the Cross River State of Nigeria. It occupies an area of about $640 \mathrm{Km}^{2}$ (MINEFI, 2008). The study area has a humid tropical climate, characterized by a single short dry season (November to March) and corresponding long wet season (April to October). The mean annual rainfall for the period of study $(2006$ - 2007) was about $1134 \mathrm{~mm}$ with a gradual decrease from South to North, and monthly peaks in July and August of every year (Gartland, 1986, Besongabang Weather Station 2003;)

The mean monthly temperature ranged between $24^{\circ} \mathrm{C}$ and $27^{\circ} \mathrm{C}$ in February and January respectively and a maximum of $33.9^{\circ} \mathrm{C}$ in March of every year (Gartland, 1984; Besongabang weather station 2003, 2005)

The area is flat, with an altitude of approximately $150 \mathrm{~m}$ above sea level, rising towards the north, to the Akwaya Highlands. The area is drained by Rivers Munaiya in the North, and centrally by River Awa.

The vegetation of the area is of a closed-canopy, moist evergreen lowland rain forest of the Guinea-Congolian type (White, 1993).

\section{METHODOLOGY}

The study employed Biological PRA, questionnaires, visual assessments, and key-in formats, for the collection of data on the prevalence and the economic potentials of NTFPs in the study area.

\section{SITE SELECTION}

The study area was divided in to three main zones $\mathrm{A}, \mathrm{B}$ and $\mathrm{C}$ based on the level of accessibility by motorable road.
ZONE A:

This consisted of villages that were $100 \%$ accessible by motorable roads.

ZONE B: $\quad$ This consisted of villages that were $45 \%$ accessible by motorable roads and $55 \%$ by foot path.

ZONE C: $\quad$ This consisted of villages that were not accessible at all by motorable roads but by foot paths only.

From each of the zones, six villages were selected randomly form the main target groups listed below, using the lucky deep balloting method. A total of 18 out of 28 villages were therefore selected for the study. In each of the 18 villages, 50 questionnaires were administered giving a total of about 300 questionnaires per zone and 900 questionnaires in all. The sampling intensity with respect to the population was approximately $10.3 \%$.

\section{Selection of Respondents}

Respondents to the questionnaires were purposively selected from 6 target-groups: (Village Traditional Council members, Traders of NTFPs, NTFP collectors/gatherers and harvesters, hunters, Agricultural and Forestry Extension Staff, and Forest Users Groups).Each of the target groups received 5 questionnaires.

\section{Questionnaires Design}

A set of Questionnaire divided into four sections A, B, C and D. was employed for the collection of data for the study. Sections A and B collected information on the types, harvesting, gathering, processing and storage methods for the NTFPs. Section $C$ and $D$ focused on the trade channels and the cross boarder trade between Cameroon and Nigeria.

\section{Transects establishment}

In order to complement the socio-economic data collected on the identified NTFPs in the study area, the Line Transects Technique was employed for the enumeration of the traded NTFPS species. In each of the selected villages in the three zones, 3 one $\mathrm{km}$ transects were established perpendicular to the main access roads of the area. (Mamfe-Ekok access and the Eyumojock-Out access roads). Along each transect, within the range of $20 \mathrm{~m}$ on both sides, a $100 \%$ inventory of all the NTFPs species sited, were identified and enumerated.

\section{ANALYTICAL PROCEDURE}

Descriptive statistics and SPSS were employed for data analysis.

\section{RESULTS}

\section{Identified NTFPs of the study area}

As indicated in table 1, 36 NTFPs species were identified in the study area, on which the local inhabitants depend on for their livelihoods. These ranged from leaves, to seeds, stems, barks, gum, fruits and construction materials, local craft, food and medicine. 
Table 1: Identified NTFPs, sources and relative abundance in the Study Area

\begin{tabular}{|c|c|c|c|c|}
\hline Common Names & Scientific Names & Family & Sources & $\begin{array}{c}\text { Level of } \\
\text { abundanc } \\
\mathrm{e}\end{array}$ \\
\hline 1. Bush pepper & 1. Piper guineensis & 1. Piperaeceae & $\begin{array}{l}\mathrm{PF} \\
\mathrm{SF}\end{array}$ & +++ \\
\hline 2. Bitter kola & 2. Gacinia cola & $\begin{array}{l}\text { 2. Clusiaceae/Guttifer } \\
\text { ae }\end{array}$ & $\begin{array}{l}\mathrm{PF} \\
\mathrm{SF}\end{array}$ & ++ \\
\hline 3. Native kola & 3. Cola acuminata. & 3. Malvaceae & $\mathrm{FL}$ & ++ \\
\hline 4. Eru & 4. Gnetum africanum & 4. Gnetaceae & $\begin{array}{l}\text { PF } \\
\text { SF }\end{array}$ & ++++ \\
\hline 5. Eru & 5. Gnetum buchholzianum & 5. Gnetaceae & $\begin{array}{l}\mathrm{PF} \\
\mathrm{SF}\end{array}$ & ++++ \\
\hline 6. Bush mango & 6. Irvingia gabonensis & 6. Irviniaceae & $\mathrm{FL}$ & ++ \\
\hline 7. Bush mango & 7. Irvingia wombolu & 7. Irviniaceae & $\begin{array}{l}\mathrm{PF} \\
\mathrm{SF}\end{array}$ & +++ \\
\hline 8. Njangsang & 8. Ricinodendron heudoloti & 8. Euphorbiaceae & FL $F$ & +++ \\
\hline 9. Yoruba sticks & 9. Masularia acuminata & 9. Rubiaceae & $\begin{array}{l}\text { PF } \\
\text { SF }\end{array}$ & ++ \\
\hline 10. Igbo sticks & 10. Garcinia manii & 10. Clusiaceae & PF & ++ \\
\hline 11. Hausa sticks & 11. Carpolobia lutea & 11.Polygalaceae & $\mathrm{PF}$ & ++ \\
\hline 12.Country onion & 12. Afrostyrax lepidophyllus & 12. Huaceae & $\mathrm{PF}$ & +++ \\
\hline 13.Raffia & 13. Raffia vinifera & 13. Arecaceae. & $\mathrm{PF}$ & +++ \\
\hline 14.Bush meat & 14. Animals of all kinds & 14. & $\mathrm{PF}$ & +++ \\
\hline 15.Ngongo leaf & 15. Turmatocucoa danieli. & 15. Marantaceae & $\mathrm{PF}$ & +++ \\
\hline 16.Oil palm & 16. Elaeis giuneensis & 16. Arecaceae & SF & ++++ \\
\hline 17.Palm wine & 17. Elaeis giunensis & 17. Arecaceae & $\mathrm{PF}$ & +++ \\
\hline 18.Mushroom & 18. Fungi sp. & 18. & SF & ++++ \\
\hline 19.Shea nuts & 19. Pogal oleosa & 19.Rhizophraceae & $\overline{F L}$ & +++ \\
\hline 20.Rattan cane & 20. Rattan $s p$. & 20. Arecaceae & $\mathrm{PF}$ & ++ \\
\hline 21.Esekeseke & 21. Tetrapleura tetraptera & 21. Leguminosae & SF & +++ \\
\hline 22.Alligator pepper & 22. Aframomum melegueta & 22. Zingibereaceae & $\mathrm{PF}$ & ++ \\
\hline 23.Bush Read & 23. Canaruim schwein furthii & 23. Burseraceae & $\mathrm{SF}$ & ++ \\
\hline 24 Plums & 24. Dacryodes edulis & 24. Burseraceae & $\mathrm{FL}$ & ++ \\
\hline 25.Achi & 25. Brachystegria spp. & 25. Leguminosae & $\mathrm{PF}$ & ++++ \\
\hline 26.Star apple & 26. Chryosophylum albidum & 26. Sataceae & SF & ++ \\
\hline 27.Medicinal plants & 27. Anatia chloranta & 27. Zingiberaceae & $\mathrm{FL}$ & +++ \\
\hline 28.Medicinal plants & 28. Cylicodiscus gabonensis & 28. Zingiberaceae & $\mathrm{PF}$ & ++++ \\
\hline 29.Njabe (Moabi) & 29. Baillonella toxisperma & 29. Apocynaceae & SF & ++ \\
\hline 30.Indian Bamboo & 30. Bamusa vugaris & 30. Anacardaceae & $\mathrm{FL}$ & ++++ \\
\hline 31.Raffia Bamboo. & 31. Raffia.hookerii & 31. Anonaceae & $\mathrm{PF}$ & ++ \\
\hline 32.Rafia Bamboo & 32. Raffia farinefe & 32. Anacardaceae & SF & +++ \\
\hline 33.Bush Plum & 33. Canarium schweinfurthi & 33. Anonaceae & $\mathrm{PF}$ & ++ \\
\hline 34. Kola nuts & 34. Kola nictida & 34. Marantaceae & $\mathrm{PF}$ & +++ \\
\hline 35.Monkey cola & 35. Cola lipidota & 35. Leguminosae & PF & ++ \\
\hline 36.Bush yam & \multirow[b]{2}{*}{$\begin{aligned} & \text { 36. Dioscorea spp. } \\
= & \text { Less abundant } \\
= & \text { Very abundant } \\
= & \text { Primary Forest } \\
= & \text { Fallow Land }\end{aligned}$} & 36. Apocynaceae & $\mathrm{PF}$ & +++ \\
\hline $\begin{array}{l}+ \\
+ \\
+++ \\
\text { PF } \\
\text { FL }\end{array}$ & & $\begin{array}{l}++ \\
++++ \\
\text { SF } \\
=\text { Farn }\end{array}$ & \multicolumn{2}{|c|}{$\begin{array}{l}=\text { Abundant } \\
=\text { Highly abundant } \\
=\text { Secondary Forest } \\
\text { m land }\end{array}$} \\
\hline
\end{tabular}

Trans- boundary tradable NTFPs of the Study Area

As shown in table 2; pair wise rankings using

Trade asthe main criteria, indicated that five major NTFPs sourced from the study area, are traded between Cameroon and Nigeria. 
Table 2: Tradable NTFPs of the study area between Cameroon and Nigeria

\begin{tabular}{|c|c|c|c|c|c|}
\hline $\begin{array}{c}\text { Common } \\
\text { Names }\end{array}$ & Scientific Names & Family & \multicolumn{2}{|c|}{ Sources } & $\begin{array}{c}\text { Level of } \\
\text { abundance }\end{array}$ \\
\hline Bush mango & Irvingia gabonensis & Irviniaceae & PF & SF & +++ \\
\hline Bush mango & Irvingia wumbolu & Irviniaceae & PF & SF & +++ \\
\hline Eru & Gnetum africanum & Gnetaceae & $\mathrm{FL}$ & & ++++ \\
\hline Eru & Gnetum buchholzianum & Gnetaceae & PF & SF & ++++ \\
\hline Hausa sticks & Carpolobia lutea & Polygalaceae & $\mathrm{PF}$ & & ++ \\
\hline Hausa sticks & Carpolobia alb & Polygalaceae & PF & & ++ \\
\hline Yoruba stick & Masularia acuminata & Rubiaceae & PF & SF & ++ \\
\hline Igbo sticks & Garcinia manii & Clusiaceae & PF & & ++ \\
\hline Njangsang & Ricinodendron heudoloti & Eurphobieceae & SF & & +++ \\
\hline $\begin{array}{l}=\text { Les } \\
=\text { Ver } \\
=\text { Prir } \\
=\text { Fall }\end{array}$ & $\begin{array}{l}\text { abundant } \\
\text { bundant } \\
\text { y Forest } \\
\text { Land }\end{array}$ & $\begin{array}{l}S \\
F\end{array}$ & & $\begin{array}{l}\text { Indar } \\
\text { hly a } \\
\text { ond } \\
\text { on lar }\end{array}$ & $\begin{array}{l}\text { undant } \\
\text { y Forest }\end{array}$ \\
\hline
\end{tabular}

Harvesting, gathering and collection of tradable NTFPs

Investigations in this sector were limited to the five tradable NTFPs of the area. This was in view of the fact that any forest product that emerges as an article of international trade, is usually subjected to over exploitation, miss use and resource degradation by the surrounding forest edged population, (Nkwatoh, 2007). It is from this backdrop that it became imperative to examine the impact of this trade on the sustainability of tradable NTFPs.

\section{Irvingia gabonensis (Bush mango)}

When Irvingia fruits get ripe, they fall to the forest floor where they are collected by the collectors and carried home or to the camps for processing. The fruits are broken open using a cutlass, stone or a hammer, following a natural line on the fruit to get the cotyledon (kernel). When the fruit is broken open, a small knife tip is used to remove the two halves of the kernel for drying. After drying to a desirable level, the product (dried kernel) is ready for marketing.

In the market, the product is measured in cement bags, 15 litre bucket or semi basins as major unites of market measurements and sold as such. The marketing of this product is associated with a grading system, which is a function of its processing quality and technique. The collection/gathering and processing of this product is characterised by resource degradation as in most cases ripe and fallen fruits are all collected/gathered for processing with no fruits left to behind to germinate in to seedlings for the conservation of the parent stock.

\section{Gnetum africanum and buchholzianum (Eru)}

Gnetum is harvested by plucking off the leaves of a forest vine, as harvesters move from one portion of the forest to another. The harvested leaves are tied into marketable bundles using the small stems of the parent vines as ropes, and then put into a $200 \mathrm{~kg}$ bag. The harvesters return to the village only when the $200 \mathrm{~kg}$ bag is full. In situations where the $200 \mathrm{~kg}$ bag is not full, they sometimes camp in the forest (sleeping bush) and continue harvesting on the next day until a full bag is obtained. The harvesting of Gnetum is characterised by the pulling down of the climbing vine and the use of vine stems as ropes leading to resource degradation and depletion.

\section{Carpolobia lutea and Carpolobia alba (Hausa sticks)}

The harvesting of mature plants is done throughout the year.

The harvesting of Carpolobia is done using very sharp locally produced axes to cut the plant very close to the ground or below ground level. This cutting leaves an average stump height of less than $1 \mathrm{~cm}$ above ground level and some cases cut below ground level. In any ten harvested cases in the study area, 6 were cut below ground level. The harvested plants are debranched, cut into a commercial length of $1.8 \mathrm{~m}$ and tied into small bundles of about 20 stems per bundle. The small bundles are then transported from the point of harvesting to roadsides or riversides that served as points of bundle rearrangements and grading for further transportation to the Nigerian market centers of Ikom and Yola.

\section{Masularia accuminata (Chewing sticks)}

Masularia spp stems are harvested in the forest using a locally made axe or a cutlass. The product after harvesting is cut into lengths of one metre each, and tied into bundles, containing about 27 to 50 stems. The stems are then transported to the river or roadside by head load, where they are transported in Lorries or boats to the Nigerian market.

Ricinodendron heudeloti (Njangsang) Fallen fruits at the bottom of the trees are gathered and heaped under the trees and left for one to two weeks for their mesocarps to gets rotten. When rotting is completed, the mesocarps are washed away to get the stony seeds which are processed for the market. Here harvesting is sustainable.

\section{Market Channels}

As shown in fig 1 , over $75 \%$ of NTFPs produced in the study area are sold in Nigeria, while about $15 \%$ are sold in and around the villages for local consumption. 


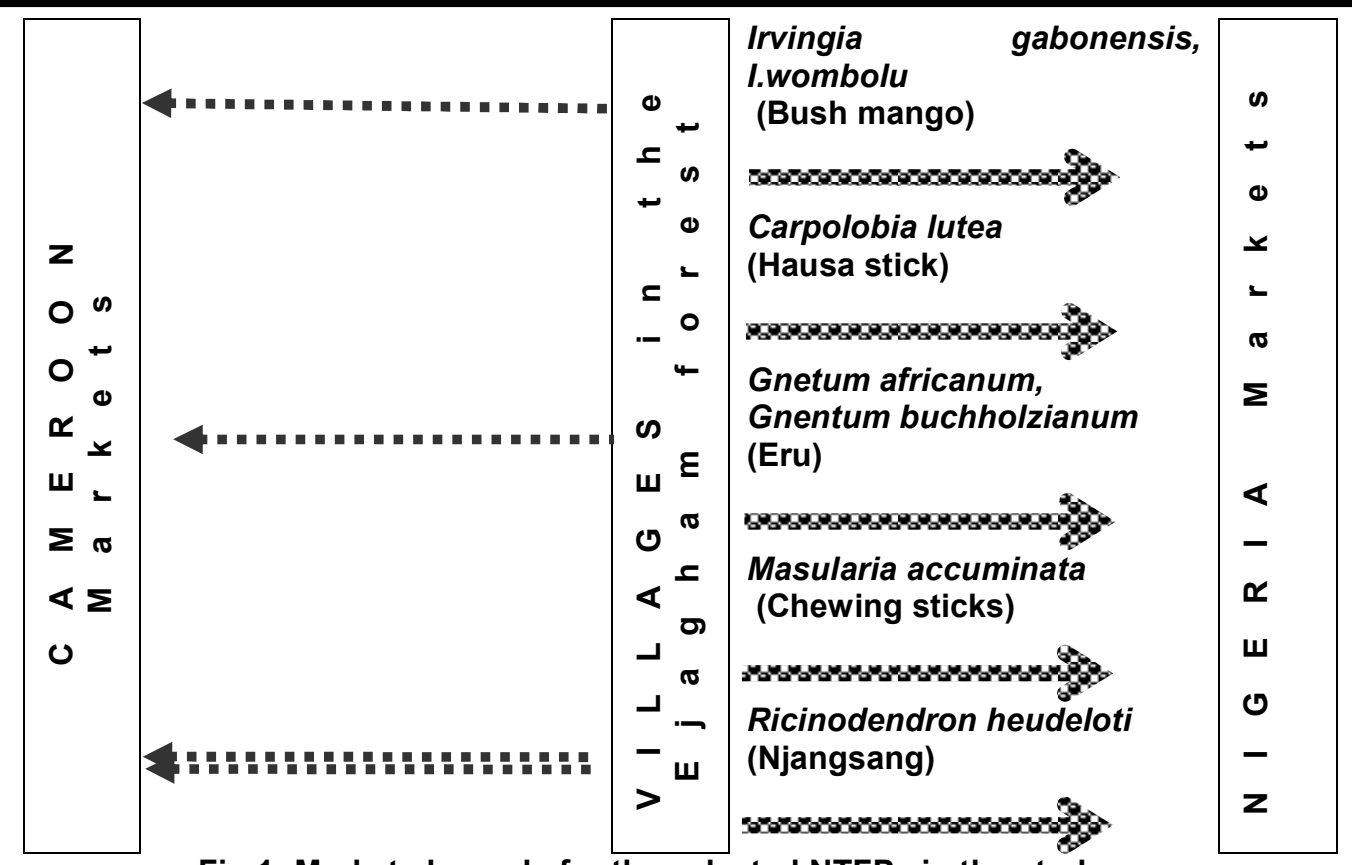

Fig 1: Market channels for the selected NTFPs in the study are

In the middle of the diagram, are villages in the study area. From these villages, the doted arrows to the left show the $15 \%$ market channels in Cameroon while the thick and bigger dotted arrows to the right show the $75 \%$ market channels that are traceable into Nigeria.

\section{DISCUSSION}

The list of over 36 NTFP species identified to be sourced from the study area for various uses do not in any way represent an end list of NTFPs for the area. In view of the fact that the study area is a home to a wide range of plant and animal species whose values have not yet been identified by the local people, whenever these are identified as resources to them or to other communities elsewhere on the globe, there will obviously be an extension of this list. Nkwatoh, (2000) put it that, Masularia acuminata was not on the Ejagham list of NTFPs before 1990. Its inclusion on to the list of NTFPs for the Ejagham people was only after Nigerian chewing stick traders visited the area in 1992 in search of this plant.

Out of the 36 species of NTFPs for the area, five NTFPs with high trade and market potential on which the people of the area depend for the support of their rural income were already facing degradation as a result of over exploitation and the use of unsustainable traditional collection methods, which are eco-system destructive. This is in line with the findings of Ndonye (1995); Vabi (1995a 1995b), Falconer (1995), Okafor (1987) and Nkwatoh (2000), who individually in their various investigations, demonstrated that when an NTFP becomes an article of trade, its resource base risk depletion because of unregulated lifting of the resource by the local population. The steady drop of the standing stock of NTFPs in the study area from zones $A$ to $C$ is not unconnected to the fact that zone $A$ faces a high pressure from collectors because of its ease of accessibility to traders of NTFPs due to its relatively better road infrastructure. On the other hand, zone $\mathrm{C}$, because of its inaccessible nature received a low level of pressure from collectors whose frequency of collection is demotivated by the small number of buyers ready to buy their produce as well as the low economic returns from its harvesting

The collection, harvesting and gathering methods for some of the NTFPs (Irvingia, Gnetum, carpolobia and Masularia) were observed to be unsustainable and characterized by the use of rudimentary tools. During seasons of low productivity for the Irvingia species, collectors usually collect every fruit that falls to the ground for processing. This gives no room for the development of saplings. Common property right phenomenon in traditional resource management system is that, what ever generates enough income and belongs to the whole community suffers the fate of being over-exploited. This is what is expected in the study area in the long run if strong control measures are not put-in place (Nkwatoh, 2007).

One of the major challenges facing the development and conservation of the NTFPs sector in the area and Cameroon in general is the difficulties and problems associated with the processing of these products for the market. Species like Njangsa (Ricinodendron) seem to be one of the most difficult NTFPs to be processed for the market. On the other hand the harvesting of Carpllobia and Masularia were done with impunity leaving no room for the parent stock to regenerate its kind. This is an indication that the study area, which is today a home to these species, could become void of them in the near future (FAO, 2001, Nkwatoh, 2000, 2007).

There exist a great trade in NTFPs from the study area with Nigeria. Though a few of these products are marketed in Cameroon; if you take away the Nigerian market, NTFPs such as Masularia and Carpolobia will loose the market value they now treasure. NTFPs such as Irvingia and Gnetum species will also comfortably 
experience a sharp drop in their economic value and risked being rated like any other NTFP, which is valued only for its household use. FAO (1995), Ndouye and Nicodem (1994) and Nkwatoh (1995), stated that, without the Nigerian market, the economic potential for NTFPs in the Congo Basin is lost.

\section{CONCLUSION AND RECOMEMDATIONS}

There exist a great trade in NTFPs from the study area with Nigeria. In the light of the above, it is recommended that trade barriers such as cross border taxes and check points be reduced on these products to encourage the growing trans-boundary trade and bilateral co-operation between Cameroon and Nigeria.

\section{REFERENCES}

Adeyoju, S.K., 1975. Forestry and the Nigerian Economy, University Press Ibadan.

Besongabang, Weather Station, 2003. Annual Weather Report: for the Provincial Delegation of Weather Observation and Monitoring, South West Province Cameroon. 11-17pp.

Docan, W.T. and Mbenkum, F.T., 1987. Medicinal and food plants from Cameroon's Forest Development and Conservation. UNDP/FAO Forest Sector Review of Cameroon, InterAgency joint mission to Cameroon, 48pp.

Docan, W.T. James, M.T. Wendy, A.B. and Fonki, T.M., 1989. Korup ethnobotanical survey. Final report to the World Wide Fund for Nature.

Egunjobi, J.K. and Lawal, K.M., 1993. Proceedings of the Conference on Environmental Resources Management of Nigeria. University of Ife, Nigeria, 31-37pp.

Falconer, J., 1990. Non-Timber-Products in Ghana's Forest zones: Issues for forest conservation. In Conservation of West and Central African Rainforest, edited by Kavin Cleaver; Moham M.; Mary O.; Nicolas E.; Axel, P; Francis W.; World Bank environmental paper (1): (6771).

Falconer, J., 1992. Non-Timber-Forest-Products in Southern Ghana. A summary Report. ODA Forestry series No. 2 Natural Resources Institute Chatam.

Falconer, J., 1995. The major significance of minor forest products. The local use and values of forest in the West African Humid Forest zones. Community Forestry Note. No. 6. FAO Rome.

Food and Agricultural Organisation (FAO), 1995. Forest Resources Assessment 1990. Survey of Tropical Forest Cover and study of change processes. FAO Forestry paper No. 130 Rome.
Food and Agricultural Organisation (FAO), 1998. NonWood Forest Products of Central Africa: Current Research Issues and Prospective for Conservation and Development. Edited by Terry C.H Sunderland, Laurie E. Clark and Paul Vantomme.288p.

Food and Agricultural Organisation (FAO), 2001. NonWood Forest Products in Africa: A Regional and National Overview. Edited by Sven Walter.

23-68 and 190-303.

Gartland, J.S., 1984. The African forest and problems in conservation. Symposium: $5^{\text {th }}$ International Primate Society, U.K.

Gartland, J.S., 1986. The biological and historical importance of Korup Forest. In J.S. Gartland and $\mathrm{H}$. Macleod (Eds), Workshop on Korup National Park. Mundemba, Cameroon WWF/IUCN Project 3206.

Ladipo, D.O., 1995. Collection and Conservation of the Genetic Resources of Irvingia gabonensis in West and Central Africa. Unpublished Report. ICRAFT. Nairobi, Kenya.26pp.

Ministry of Plan and Regional Development (MINPAT), 1987. National Population and Housing Census of Cameroon Report, 674pp.

Ministry of Finance and the Economy (MINEFI), 2008. National Institute of Statistics. Cameroon Statistical Yearbook 2007. December20072008 245pp.

Ndouye, O. and Nicodeme, T., 1994. Utilization and marketing of Irvingia gabonensis products in the humid forest zones of Cameroon. Rockefeller Foundation Post Doctoral Fellowship Report at IITA station, Yaoundé, Cameroon.111pp

Ndouye, O. Ruiz-Perez, M. and Ayebe, A., 1998. NTFPs markets and potential sources for forest resource degradation in central Africa. The role of research for a balance between welfare improvement and forest conservation. Paper presented at the International Export Workshop on NTFPs for Central Africa. Limbe Botanical Garden, Cameroon.

Ndouye, O., 1995. Commercialisation and diversification opportunities for farmers in the humid forest zones of Cameroon: The case of Non-Timber- Forest-Products. Consultancy report for an Alternative to Slash and Burn Project (ASB).

Ndouye, O. Ruiz-Perez, M, and Ayebe, A., 1997. The markets of Non-Timber-Forest-Products in the humid zones of Cameroon. Rural Development Forestry Network. ODI, London. 
Ndouye, O. and Nicodeme, T., 1994. Utilization and marketing of Irvingia gabonensis products in the humid forest zones of Cameroon,.

Rockefeller Foundation post doctoral fellowship Report at IITA station, Younde Cameroon, $11 \mathrm{pp}$.

Nkwatoh, A.F., 1995. Production and marketing of NTFPs in the Ejagham Forest Reserve and Cross-border trade in NTFPs with Nigeria. A Report prepared for GTZ Korup Project Cameroon.

Nkwatoh, A. F., 2000. Evaluation of Trade in NonTimber Forest Products in the Ejagham Forest Reserve of South West Cameroon. Ph.D. Thesis University of Ibadan (un published.) 167 pp.

Okafor, J.C., 1987. Development of forest tree crops for food supplies in Nigeria. Forest Ecology and Management Journal 1: 235-247.

Okafor, J.C., 1981. Wood plants of nutritional importance in traditional farming systems of Nigeria's humid tropics. Un published PhD thesis, Ibadan, Nigeria; 176pp.

Okafor, J.C., 1986. Towards diversification and improvement of alley-farming systems in Nigeria's humid tropics. Paper, presented at the 1986 Annual Conference of the Forestry Association of Nigeria un published.
Omoluabi, M.C., 1994. Market margins in Non- TimberForest-Products trade in Cross River State of Nigeria. Working paper No. 12 prepared for the Cross River Forestry Project, Calabar, Cross River State, Nigeria.

Paddock, C. and de Jong, W., 1995. Production and profits in agro forestry: an example from the Peruvian Amazon. In J.G. Browder, ed. Fragile lands of Latin America. Strategies for sustainable development. Boulder, Colorado. USA.

Popoola, L. and Oluwalana, S. A., 1998. Marketing of NTFPs in Nigeria. Paper presented at the colloquium on Biodiversity (RainforestEcosystem of Nigeria). Organised by FEPAUNAAB.

Vabi, M.B. 1995. Community knowledge and traditional uses of trees in some village communities of Cameroon and the Central African Republic. Paper prepared for the Regional symposium on Agro-forestry Research and Development in the Lowlands of West and Central Africa.

Vabi, M. B., 1995. Determining economic opportunity for inhabitants of some villages in the support zone of the Korup National Park. Report prepared for GTZ Korup Project with particular reference to NTFPs and Gender.

White, F., 1993. The vegetation of Africa. UNESCO Publications 126 (52): Paris. 
